\title{
Ever larger unions: organisational restructuring and its impact on union confederations
}

\author{
Bernhard Ebbinghaus
}

\begin{abstract}
Unions have responded to current membership decline and other organisational problems by restructuring via mergers, increasing union concentration within and across union confederations. A particular noted feature are amalgamations to form 'super-unions'. These conglomerate unions threaten to undermine the role played by confederations in respect of political voice, bargaining coordination, and service provision. Despite these mergers, union pluralism still prevails in many European countries with separate peak associations organised along employment/occupational status or political and religious lines. After comparing the recent merger waves and increased union concentration in western European countries, the consequences for union movements are discussed.
\end{abstract}

Potential strategies for unions to overcome their structural problems have gained increasing attention in recent years. As part of such efforts towards labour movement 'revitalisation', the issues of mobilisation and restructuring are particularly relevant. Last year's annual review (Ebbinghaus, 2002b) concentrated on the challenge of deunionisation; this year, the analysis will be concerned with strategies for organisational change. In order to mobilise and retain members, unions have in some countries become increasingly dependent on 'union securities' provided by the welfare state such as sheltered public sector employment, statutory workplace access, union-run unemployment insurance, involvement in social concertation and the selfadministration of social insurance. Unions have had varying success in organising the new workplaces, innovative sectors, atypical employment groups, and the rising female labour force as well as young people. Some of the challenges facing unions are

\footnotetext{
$\square$ Bernhard Ebbinghaus is Senior Researcher at the Max Planck Institute for the Study of Societies. Correspondence should be addressed to Bernhard Ebbinghaus, Max Planck Institute for the Study of Societies, Paulstr. 3, D-50676 Cologne, Germany; ebbinghaus@mpi-fg-koeln.mpg.de
} 
due to structural changes that lead to a stagnating or declining workforce in traditionally well-organised sectors, increased company mergers and restructuring across former sectoral boundaries, and the growth of new workforce segments that are thus far hardly organised. As a response to the membership problems and structural workforce changes, unions have engaged in union restructuring.

Union mergers have become a common feature over the last two decades, and largescale amalgamations have attracted special attention in recent years (Waddington and Hoffmann, 2000). As a consequence of mergers union concentration is increasing. Fewer but larger unions, which tend to straddle across many sectors and occupational groups, organise an increasing share of all union members. The concentration of unions also entails major repercussions and a changing role for union confederations, shifting the balance of power among member organisations towards the larger and to the disadvantage of the smaller ones. With increased size, the relative power of the new 'super-unions', threatens to undermine the role played by confederations in political voice, bargaining coordination, and service provision. Nevertheless, union confederations are still playing an important role, particularly in national politics and to a lesser extent in social concertation (Berger and Compston, 2002; Fajertag and Pochet, 2000; Molina and Rhodes, 2002). Moreover, union pluralism still prevails in many countries, leading to separate peak associations along employment and occupational status or political and religious lines (Ebbinghaus, 1996). A trend towards the separation of left-wing political parties from allied union confederations is however providing new opportunities for greater inter-union cooperation if not the chance to reunite divided union movements.

Union fragmentation and the plurality of unions have traditionally made the coordination of wage policies more difficult. On the other hand, union concentration and a unified union confederation facilitate efforts to represent both the economic and political interests of workers. Yet union restructuring also responds to the transformation of collective bargaining. Where decentralisation of collective bargaining has increased, unions need to spend more administrative resources, increase the capacity for internal coordination and to extend their workplace strength by maintaining wage solidarity. Also in those cases where social concertation has become common, restructuring within and across union peak associations has repercussions for the capacity of organised labour to coordinate a joint position vis-à-vis the government and employers. In the following, we will first analyse the current merger wave leading to increased union concentration. Thereafter, we will discuss the changing role of union confederations and the consequences for union pluralism. Trends and differences in union restructuring will be outlined by comparing recent organisational developments in Anglo-Irish, Nordic, Continental European and Southern European union movements. ${ }^{1}$ This grouping of countries allows a comparison of union movements that have shown, at least thus far, some similarities in the structure of union systems and union confederations.

\section{Union restructuring through mergers}

In response to external social and economic changes as well as internal financial and membership problems, trade unions across Europe have, over the last few years restructured through numerous mergers. So-called 'super-unions', creating large-scale organisations spreading across major parts of the economy, emerged most recently in the Netherlands (1998), Finland (2000), Germany (2001), and the United Kingdom (2002). Elsewhere several unions in Austria, Denmark, Sweden and Switzerland plan similar large-scale mergers for the future. At the same time, amalgamations of

\footnotetext{
${ }^{1}$ Information on current events is drawn from the national news and comparative reports made available through EIROnline (www.eiro.eurofound.ie) and the published newsletter European Industrial Relations Review (EIRR). Organisational data (see Tables 1) is from the Trade Unions in Western Europe database and handbook (Ebbinghaus and Visser, 2000), which has been updated from various national sources by the author.
} 
medium-sized unions or the absorption of smaller unions by larger ones occurred in nearly all European union movements. However, mergers are not a new phenomenon: organisational restructuring has occurred continuously in such different union movements as in Britain, the Netherlands and Sweden (Visser and Waddington, 1996). However, one qualitative difference between recent and former merger waves is the scale and spread of the resulting conglomerate unions: 'like conglomerate firms, they straddle and indeed disregard sectoral boundaries' (Streeck and Visser, 1997: 325). Moreover, large unions now follow 'aggressive' merger policies that seek to 'acquire' smaller unions and even compete over their merger targets (Undy, 1999). These features have not been limited to national union movements. At the European level, several mergers during the late 1990s led to more concentrated-albeit more heterogeneous-European Industry Federations within the European Trade Union Confederation (ETUC). ${ }^{2}$ However, the current mergers at national level have not necessarily anticipated or followed the ETUC's sector organisations. Thus instead of convergence towards similar multi-sector unions, rather diverse union structures emerged across Europe, hampering further transnational cooperation at sectoral and workplace level.

There are several external driving forces behind a union's decision to merge (Streeck and Visser, 1997; Visser and Waddington, 1996): the decline in membership (in absolute or relative terms); the waning of political power; the contraction of a union's domain; corporate restructuring in the private sector; the privatisation of public services; the decentralisation of bargaining; and concentration within and outside a union confederation. Internal reasons can also be important, such as financial problems (not least due to declining membership) which compel union leaders to pool resources and seek economies of scale- though these gains would require a reduction in union staff, often a contentious issue before and after mergers (Waddington, 2000). Unions before merging often seek concessions for the transition of leadership and staff as well as looking for partial autonomy through special section status. Although restructuring through amalgamations or absorptions seems to be a rather universal trend, there are considerable cross-national differences in the form, scope and type of these mergers (Waddington and Hoffmann, 2000). This variation accounts for several reasons, not least, the internal processes of pre-merger unions may differ widely, the external and internal reasons for restructuring may vary, and the legal or constitutional conditions (membership ballots or decisions by delegates) pose additional hurdles.

In the late 1980s and early 1990s, several 'super-unions' emerged in the relatively fragmented British and Irish union systems, instigated by severe deunionisation since the 1980s (Gall and McKay, 2000; Roche and Larragy, 1990). Most recently, the Amicus merger (2002) brings together the engineering, technicians and managerial unions MSF and AEEU. ${ }^{3}$ UNIFI, itself the result of a merger in 1999, is also considering joining Amicus's finance section. Back in 1993, UNISON was created by the three public sector unions: NALGO (local government), NUPE (public employees), and COHSE (health sector). Several other amalgamations and numerous engagements to larger TUC unions were undertaken by TUC affiliates and independent staff associations over the last decade. ${ }^{4}$ In contrast, Ireland's largest union-Services, Industrial, Professional, Technical Union (SIPTU) — was created in 1990 through the unification of the two politically divided Irish general unions (IGTWU and WUI) after they had lost more than 12

\footnotetext{
${ }^{2}$ The European Mining, Chemical and Energy Federation (EMCEF) was formed in 1996 by the European chemical workers' union (EFCWU, 1988) and miners' federation (MEF, 1991); the European Transport Workers' Federation (ETF) was reorganised in 1999; the European Federation of Food Agricultural and Tourism (EFFAT) amalgamated in 2000 two unions covering agriculture (EFA, founded in 1958) and food and catering (ECF-IUF, 1981); the European Federation of Services and Communication (UNIEuropa) was formed by a merger of communication (CI, 1965), white-collar (EURO-FIET, 1972), graphical (EGF, 1985) and media (EEA, 1993) workers' unions.

${ }^{3}$ MSF was formed by the merger of TASS and ASTMS in 1988 and AEEU by the amalgamation of AEU and EEPTU (which had been expelled from the TUC in 1988) in 1992.

${ }^{4}$ The most notable amalgamations occurred in transport (RMT, 1990), foot and apparel (NUKFAT, 1990), media (GPMU, 1991), communications (CWU, 1995), public service (PCS, 1997) and, most recently, Prospect (2001).
} 
per cent of their members over the 1980s. This merger added pressure on other Irish unions to combine in larger ICTU affiliates. ${ }^{5}$ Falling short of a full merger, the largest Irish-based craft union- the Technical, Engineering and Electrical Union (TEEU) - has entered a 'Trade Union Federation' agreement with the much larger SIPTU in 2002. However, though SIPTU retains a dominant role within ICTU, British-based unions, including the newly merged Amicus, continue to operate and compete with Irishbased unions in the Republic and in Northern Ireland.

Nordic unions have embarked on considerable reorganisation over the last two decades. Major predecessors to today's super-union mergers were two amalgamations among Norwegian industrial sector unions (Fellesforbundet in 1988) and Danish public and private service sector unions (FOA in 1992). ${ }^{6}$ In Denmark, the two general unions for unskilled workers, SID (traditionally for men since 1897) and KAD (for women since 1901), are planning a merger which would end parallel bargaining and workplace representation. In addition, the union of skilled wood and construction workers (TIB, formed by merger in 1996) is considering joining them in order to counter recent concentration among building employers. The communication workers' union (TKF) decided to join the metal workers' union in 2003, however, a similar merger of the Danish electricians' union (DEF) failed to receive the necessary support in a ballot in 2001. Also in 2001, the amalgamation of two Danish associations for unskilled kindergarten workers (PMF in LO) and skilled educators (BUPL in FTF) was rejected in a ballot of the latter union's membership. With the exception of construction, the planned mergers will not alter the fragmentation into unskilled and skilled unions in Denmark.

In Norway, the municipal workers' union (NKF), the largest affiliate within the Norwegian LO, plans to merge in 2003 with the health sector union (NHS), a former affiliate of the white-collar union federation YS. Two teachers' unions, Lererforbundet (formerly affiliated to the now dissolved peak association AF) and the independent Norsk Larerlag merged to form a new union (Utdanningsforbundet), which became the founding member of the white-collar peak association UHO (Utdanningsgruppenes Hovedorganisasjon) in December 2001. While there is a tendency towards increased concentration within and beyond the Norwegian $\mathrm{LO}^{7}$ the white-collar peak organisations remain highly fragmented and volatile in Norway. In contrast to their Nordic neighbours, Norwegian unions are subject to greater membership decline and lower union density due to the lack of union-run unemployment insurance (Dølvik and Stokke, 1998). For instance, Fellesforbundet had lost one quarter of its membership in the decade following its merger.

Swedish unions also organise along sectoral lines not only within the blue-collar confederation $\mathrm{LO}$ but also to a larger degree within the white-collar peak associations TCO and SACO (Kjellberg, 2000). Nevertheless, consolidation of sectoral unions in adjacent sectors has occurred occasionally over the last decade. Two planned mergers will compete for the third rank within the Swedish LO: the commerce workers' union (Handels, currently ranked fourth) and the transport union have entered merger talks, while the public sector union SEKO and the smaller private sector unions of printers (GF) and electricians (SEF) are considering a merger. This will increase the pressure on smaller unions: for example, the agricultural workers' union (SLF) joined the municipal workers' union (SKAF) in 2002. However, reorganisation plans may fall

\footnotetext{
${ }^{5}$ Amalgamations involving medium sized Irish unions during the 1990s were IMPACT (1991), TEEU (1992), and MANDATE (1993).

${ }^{6}$ In Norway, Fellesforbundet was formed in 1988 by merger of five unions in metal, construction, textile, paper and forestry (30 per cent of LO members); in Denmark, Forbundet af Offentligt Anstatte (FOA) was a 1992 merger of the municipal employees union and the domestic workers' union (13 per cent of LO members).

${ }^{7}$ LO's three postal service, telecommunication and computer staff unions merged to form Postkom in 2000. Other smaller mergers have involved three white-collar unions in the financial sector (Finans in YS) in 1999/2000 and a merger of three public service unions ('2fo') in 2000.
} 
through as in Denmark. Here the most notable case is of one union blocking the 'Trio' merger proposal of three Swedish white-collar unions in $2001 .{ }^{8}$

A considerable merger wave is on its way among Finnish unions, even though they profit from high union density due to union-run unemployment insurance and checkoff arrangements with employers. ${ }^{9}$ In 2000, four Finnish service sector unions of commercial, hotel and restaurant workers, caretakers and technicians founded PAM (Palvelualojen Ammattiliitto), the second largest affiliate of the left aligned union confederation SAK. Other unions are planning to follow, as, for example, the chemical and textile unions which will merge in 2004. The four white-collar unions of technical and office employees in the industry have already merged to form TU (Toimihenkilöunioni) in 2001, becoming the white-collar confederation STTK's largest affiliate.

In Continental Europe, sectoral unionism was established in the postwar period in Austria and Germany, both countries witnessed no restructuring until 1978 and 1989 respectively. In contrast, a long-term concentration process took place in Belgium, the Netherlands, and Switzerland. The pressure for restructuring mounted in Germany as unions lost four million members since 1991 in the aftermath of unification (Ebbinghaus, 2002a). In the Netherlands restructuring followed substantial membership losses since the 1980s. In Austria it followed the long-term erosion of membership and recent political pressures on corporatist institutions (Ebbinghaus, 2002b) and in Switzerland as a reaction to continued membership decline (Armingeon and Geissbühler, 2000). In Belgium the exigencies of centralised sectoral bargaining led to several mergers (Arcq and Pochet, 2000).

The Austrian union confederation ÖGB has been largely unaltered with the exception of two minor mergers in 1978 and 1991, but recently the confederation proposed a restructuring plan along multi-sectoral lines triggering off different union mergers (Blaschke, 2002). In order to circumvent its break-up, the white-collar affiliate GPA proposed a merger with four other unions organising metal, chemical, food, and media workers, a super union which would straddle the private manufacturing and service sectors. ${ }^{10}$ If this merger between the more left wing blue-collar industrial unions and the more politically heterogeneous white-collar union materialises, the remaining ÖGB affiliates, mainly in the public sector, will be forced into closer cooperation, though the central government employees' union will be reluctant to do so, given its more conservative political leanings.

Since German unification, the most remarkable restructuring was the creation of the conglomerate union Ver.di in 2001 (Müller, 2001) by the independent white-collar union DAG (contributing 15 per cent of Ver.di membership) and four DGB affiliates: the large public sector and transport workers' union (ÖTV, 49 per cent), the commerce and finance union (HBV, 15 per cent), the post \& telecommunications' union (DPG, 15 per cent), and the media union (IG Medien, six per cent). IG Medien had itself been formed by a merger of the printers' union and artists' association in 1989. Ver.di straddles public sector and private services (including printing). Nearly half of its members are women and more than two thirds are white-collar employees (including nine per cent tenured Beamte). In the decade prior to the merger, the component unions of Ver.di had lost approximately 1.3 million members which they initially gained after unification, yet membership continues to fall even after the merger. The Ver.di merger has not

\footnotetext{
${ }^{8}$ The Trio-merger involved the TCO unions for municipal employees (SKTF), public administration (ST) and office clerks (HTF). The latter failed to achieve a two thirds vote in support from its delegates, while LO's social insurance union (FF) joined ST subsequently.

${ }_{9}^{9}$ Nevertheless, membership has been stagnating, particularly for blue-collar unions, and net union density levels are gradually eroding from 78.5 per cent in 1994 to 71.2 per cent in 2000 according to a new study (FI0302204F).

${ }^{10}$ By 2005, the new organisation should integrate GPA's white-collar employees in the private sector (48 per cent of combined membership); the metalworkers' union (36 per cent, now called GMT following its absorption of the textile workers' union in 2000); the food and agricultural workers' union (ANG, seven per cent, which resulted from a merger of food and agrarian workers in 1991, and may join GMT already in 2004); the chemical workers' union (GdC, six per cent); and the printers union (DJP, three per cent), which absorbed the journalist section of the artists' union in 2001 (Blaschke, 2002).
} 
been the only one; in fact it followed a wave of mergers among other DGB unions: an amalgamated chemical and mining workers' union (IG BCE), a commerce and agricultural union (IG BAU) and several transfers to the metal workers' union (IG Metall). ${ }^{11}$ Other unions in the public sector (police, teachers and railway workers) have thus far been able to abstain from mergers thanks to favourable organising conditions, while the food workers' union failed to secure a merger with a larger union.

A belated but rapid concentration took place in the Netherlands, a country with a long tradition of divisions along the lines of politics, religion and employment or occupational status (Visser, 1990). Following the merger of the Socialist and Catholic union movements in 1981, the first major rationalisation occurred within the new confederation (FNV). The most important super-union merger has been the 1998 amalgamation of three multi-sector unions in FNV-Bondgenoten: the multi-sector manufacturing union (Industriebond, contributing 51 per cent to the new union); the food industry union (Voedingsbond, 13 per cent); the transport workers' union (Vervoersbond, 16 per cent); and the private service sector union (Dibo, 20 per cent). The new union includes blue-collar workers and white-collar employees in both industrial and private service sectors, though it has made only limited headway in new occupational groups (only 19 per cent are women) and its membership is gradually eroding (one per cent annually). Within the rival CNV, the Christian industrial union merged with the transport workers' union in 1998 (after it had already absorbed the food workers' union in 1982) but the new CNV Bedrijuenbond did not integrate with the white-collar union CNV Dienstenbond, as did its FNV competitor. Other mergers occurred both within and outside the main confederations during the 1990s. ${ }^{12}$ Given the long-term decline in union density, Dutch unions have either chosen a strategy of merging towards heterogeneous conglomerate unions (Streeck and Visser, 1997) or were (so far) able to survive in particular occupational niches, particularly in the sheltered public sector.

Union restructuring has also occurred in other Continental European countries (Belgium and Switzerland) though not to the same degree. In Switzerland, the conglomerate union Syna emerged from the amalgamation of four Christian unions (manufacturing, construction, printing, and state employees) and the liberal-national union LFSA in 1998/99. Within the larger Social Democratic confederation (SGB), a large merger will take place in 2004, combining the previously amalgamated construction and chemical workers' union (GBI, 1992), the metal workers and watchmakers' union (SMUV) and the transport workers' union (VHTL). In addition, SGB's media sector union (Comedia) was formed by the amalgamation of four printing and media unions in 1999. The communication workers' union (Kommunikation) also brought together four unions, in post and telecommunications as well as the air traffic controllers, in 1998.

In contrast to other Continental European countries, the three Belgian union movements have benefited from relatively high union density (Vandaele, 2002). Restructuring occurred in the past due to the break-up into language groupings within the

\footnotetext{
${ }^{11}$ In 1996, the construction workers' union (IG BSE) and the smaller agrarian workers' union (GGLF) merged in IG BAU, which now claimed green credentials with the letter ' $U$ ' to organise the growing environmental sector ('Umwelt'). Nevertheless the new union has continued to lose members (5.6 per cent annually). The chemical workers' union (IG Chemie suffering from 20 per cent post-unification membership losses), the mining and utilities union (IG BE, after a 30 per cent decline) and the tiny leather workers' union (GL) amalgamated to form IG BCE in 1997, becoming the third largest DGB union before IG BAU, while its membership continued to decline (3.8 per cent annually). The traditionally largest union within DGB, IG Metall, acquired smaller unions of textile (GTB in 1998) and wood workers (GHK in 1999), though this did not compensate for the loss of one million members since unification.

${ }^{12}$ A merger of printers and art unions in 1997 (KIEM), following the German example a decade later; a merger of two FNV teachers unions (AOB) in 1996; a parallel CNV merger of protestant and catholic teacher unions (Onderwijsbonden CNV) in 1996; occasional absorptions of smaller occupational unions by a larger union (for example, security and police unions joined FNV's public sector union AbvaKabo in 1998 and 2000 respectively); and a new cartel of independent union federations (UOV) emerged within the white-collar confederation MHP.
} 
Christian white-collar and teachers unions, while efforts to combine are underway by the Christian unions, leading to a merger of the construction and diverse industry unions in 1991 and of the transport and communications workers' unions (Transcom, 2001). Besides the consolidation of unions in the textile and diamond sectors (TVD) in 1994, no major changes have occurred within the more concentrated Socialist confederation.

Organisational restructuring in France and Southern Europe has been less frequent and remains so far largely limited to calls for restructuring by some union confederations (French CFDT, Italian CISL, and Greek GSEE). Given the political role union confederations play in France, the pressure towards, and capacity for, organisational consolidation at the sectoral level have, so far, been less important. A partial exception is the left-reformist CFDT which has been most active in revitalisation and restructuring during the 1990s, claiming at its $45^{\text {th }}$ Congress in 2001 an increase in membership of 80 per cent since the 1990s and advanced concentration with only 20 affiliates.

Among Italy's three political union movements, the Christian union confederation has been most active in recent years. In 1999 the CISL's General Council called for a reduction of its 36 affiliates to 11 'federations'. Since then the central and local government unions have amalgamated to form a public sector union (FPS) and the agricultural and food workers' unions have merged (FAI). The smaller left-liberal confederation UIL has halved its number of affiliates over the 1990s, while the exCommunist CGIL has maintained its already concentrated structure.

Among the other Southern European countries, union restructuring efforts have been very unequal. The main Greek union confederation (GSEE) called for organisational restructuring as early as 1990, yet inaction required a repeated call in 2002. In Spain, some union consolidation, through merging sectoral unions, occurred in the main union confederations (UGT, CC.OO) during the 1990s, reducing the number of affiliates from around 20 to approximately a dozen. Portuguese union structure has been traditionally highly fragmented by regional and local divisions in both confederations: the leftist CGTP and the reformist UGT. ${ }^{13}$ Despite efforts towards political cooperation, an important role in social concertation and an increased role in bargaining at company level, union structure remains largely unchanged in Southern Europe compared to Austria, Germany, and the Netherlands. Severe obstacles remain to sectoral mergers including the prominent role confederations play in national politics; the limited bargaining function of sectoral organisations; the continuing regional fragmentation; and dual internal representation via territorial units and sectoral federations.

\section{Union restructuring and union confederations}

The recent wave of actual or planned union mergers is reflected in the long-term decline in the number of affiliates within the major union confederations (see Table 1), though there is also a counter-tendency in the emergence of new sectional unions of public employees or white-collar groups (Ebbinghaus and Visser, 2000). The restructuring has also led to an increased concentration in ever larger unions, especially where super-union mergers have occurred. Union concentration through mergers will have major repercussions for the balance of power within union confederations and the relationship between confederations and their affiliates. While small and mediumsized unions have a strong interest in pooling resources and power within a peak association, the conglomerate unions are large enough to rely on their own services, bargaining power and political influence (Streeck and Visser, 1997; Waddington and

\footnotetext{
${ }^{13}$ An important step towards consolidation is the newly created federation of three UGT-affiliated regional bank employees unions. The banking unions were crucial in UGT's founding and they profit from high union density and the administration of occupational welfare funds.
} 


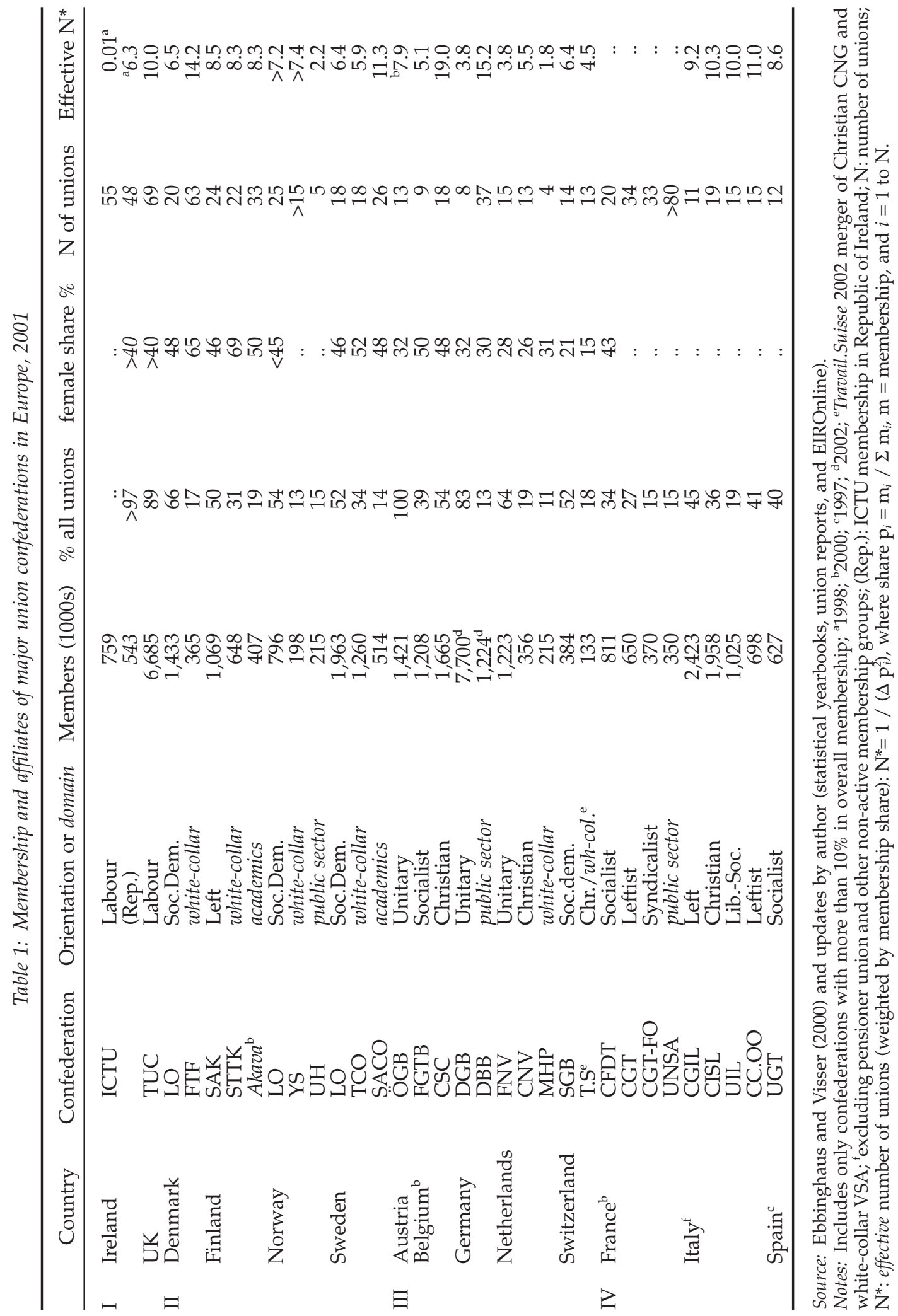


Hoffmann, 2000). Where the main union confederations have gained from corporatist arrangements, their former leading role will be undermined by both employer-driven decentralisation of collective bargaining and government-led decorporatisation. In many other countries, union confederations have never had a mandate to negotiate on behalf of their members. In such contexts national sectoral unions have always been the main bargaining partners with confederations having only a secondary coordinating and political lobbying function (Traxler et al., 2001).

Moreover, many national union systems in Europe are fragmented due to rival union confederations (see Table 1), split along employment/occupational status, sector or political lines (Ebbinghaus and Visser, 2000). The main union confederations that were founded by politically aligned blue-collar unions now face growing competition from white-collar peak associations in Nordic countries and some Continental countries. Splits along political or religious lines have also added to union fragmentation in Continental Europe. Southern European union confederations, in particular, tend to play a political role beyond the collective bargaining arena such as political mobilisation against welfare retrenchment as well as government-union concertation on welfare reforms (Ebbinghaus and Hassel, 2000). Moreover, the main labour movements-left-oriented unions and allied Social Democratic or Labour parties-have nearly everywhere in Europe de-emphasised their traditional links in order to open up to employees who do not support left wing political parties or non-union workers respectively (Ebbinghaus, 1996; Streeck and Hassel, forthcoming).

In Britain, the long-term concentration through mergers has led to a considerable reduction of TUC affiliates: from over 180 in the early 1960s to around 70 in the 1990s. At the 2002 Congress, the four largest unions (UNISON, Amicus, T\&GWU, GMB) combined represented 58 per cent of TUC membership, while none of the remaining 65 affiliates exceeds 5 per cent each. Nevertheless the absolute and effective number of unions remains comparatively high (see Table 1). ${ }^{14}$ Membership is unequally concentrated in a few very large unions and dispersed across many smaller unions, with considerable competition between and across both union types. The union-party links were already weakening prior to the election of the Labour government in 1997 and unions frequently debate withholding financial support due to differences over the government's current policies. Under the leadership of John Monks, who recently left to join the ETUC, the TUC has taken a more proactive role in union 'revitalisation' (Heery et al., 2003), founding a TUC organising academy, fostering union-employer cooperation through the Partnership Institute and backing modernising initiatives such as the 'Unions 21 ' network.

The Irish Congress of Trade Unions (ICTU) has a similarly high total number of affiliates, though the ICTU is more concentrated among its affiliates in the Republic (excluding unions and membership in Northern Ireland). The ICTU differs from the TUC due to the dominant role played by SIPTU (now allied with Irish TEEU), alongside the fragmentation of small Irish-based unions and several large British-based unions with limited membership in the Republic of Ireland. In contrast to Britain, adopting the leading role in national social dialogue has provided ICTU with the opportunity to coordinate bargaining policy among its affiliates.

The main union confederations in Nordic countries currently organise the majority of union members in the economy: Danish LO (66 per cent), Norwegian LO (54 per cent), Swedish LO (52 per cent), and Finnish SAK (50 per cent). Yet their shares of membership have largely stagnated over the last decade due to union membership concentrated among mainly blue-collar workers, though the Danish LO and Norwegian LO have made inroads into white-collar service workers. Membership is also nearly gender balanced: women represent between 45 per cent and 49 per cent. Both the Swedish LO, based on a sectoral demarcation, and the Danish LO, based on occu-

\footnotetext{
${ }^{14}$ The effective number of affiliates (Table 1) is based on the number of affiliates weighted by the square of their share in the confederation's membership; the indicator follows the 'effective number of parties' index (Lijphart, 1984: 120).
} 
pational unionism, have reduced their number of affiliates to less than 20, while the Finnish SAK and Norwegian LO have slightly more affiliates (around 25) and are less concentrated despite past restructuring. ${ }^{15}$ The main Swedish and Finnish union confederations, composed of mainly blue-collar unions traditionally aligned to the Social Democratic party, operate within a union movement of larger and growing peak confederations for white-collar workers (Swedish TCO, 34 per cent; Finnish STTK, 31 per cent) and peak associations for professionals, academics and higher-grade civil servants (Swedish SACO, 14 per cent; Finnish Akava, 19 per cent). Both the Danish LO and Norwegian LO compete with weaker and more fragmented white-collar confederations but also have more potential overlap between their own members and lower white-collar grades. ${ }^{16}$

In order to attract non-political white-collar employees, the main Nordic union confederations have moved in recent years to de-emphasise their political ties. The Swedish LO had already severed collective membership links with the Social Democratic Party in 1987, though it still maintains informal ties, particularly useful during the party's incumbency in government since 1994. In early 2003, an extraordinary congress of the Danish LO decided to end financial support to the Social Democrats after interlocking leadership ceased in 1995. The 'new LO' was also restructured. A more flexible and effective management body with four LO officers and eight union leaders selected by the twenty affiliates replaced the executive committee. In Norway, the LO president declined a seat on the Norwegian Labour Party (DnA) in 2002, although the LO (and some of its affiliates) still support the party financially and politically in election campaigns. For the future, they are seeking to develop more informal links, not least in order to facilitate the integration of white-collar unions, which are traditionally remote from the labour party. For instance, the former YS-affiliate NHS plans to merge with LO's thus far left-leaning municipal union. As a consequence of increased inter-union cooperation in tripartite talks, the Finnish SAK entered talks about a potential merger with two white-collar peak associations in 2001-a historic step if carried out in the future.

Although they have gained from high union density, Nordic unions have continued restructuring in the face of stagnating or slowly declining membership. The blue-collar dominated unions attempt to increase their bargaining power and pool their resources by mergers, de-emphasising political ties in order to attract white-collar employees, and even contemplating potential mergers with the white-collar peak associations.

Inclusive unionism organising all employees in one firm in one union and overcoming political and status divisions, has been the postwar aim of the Austrian, German and Dutch unitary union movements (Visser, 1990). The merger wave in recent years has consolidated the German DGB and the Dutch FNV as currently the most concentrated union movements in Europe (each with less than four effective affiliates, see Table 1). The Austrian ÖGB will soon follow their example with the planned merger of private white-collar and blue-collar workers' unions. ${ }^{17}$ Today, the Austrian ÖGB, Dutch

\footnotetext{
${ }^{15}$ The planned mergers within the Danish LO and Swedish LO will lead to further concentration into a few large unions (from 20 to 17, and from 18 to 12 respectively). The largest three unions already combine around 60 per cent of membership, which will increase after the mergers to over 70 per cent (the largest four to over 80 per cent).

${ }^{16}$ The Danish white-collar peak association (FTF) organises 17 per cent of Danish union membership in over 60 affiliates, compared with the central organisation of academics AC (seven per cent in 19 affiliates) and a dozen other independent unions (including the Christian workers' union). In Norway, outside the LO, the organisational field remains fragmented and volatile: the white-collar confederation YS (combines 14 per cent of overall membership in over 15 affiliates); a dissolved federation of academics (AF) in 2001; Akademikerne (a 1997 AF-breakaway with eight per cent and over 14 affiliates); the founding of a new post-AF peak association (UH, 15 per cent in five unions); and a dozen independent associations (10 per cent).

${ }^{17}$ After the merger, planned for 2005, the number of ÖGB's affiliates will decline from 13 to 9 (the effective number from 7.9 to 4.3 ). As a result, two thirds of all ÖGB members would be concentrated in the three largest unions (85 per cent in the five largest).
} 
FNV and German DGB are officially independent of party links, though union leaders are often Social Democrats (more rarely Christian Democrats or Greens). The Austrian ÖGB allows political factions, who also play an important role in social and workplace elections. This enabled it to maintain its monopoly despite calls by nationalist FPÖ party members to create independent unions. With the integration of the DAG into the DGBaffiliated Ver.di, the German post-war competition over white-collar members has largely ended, though not in the case of tenured civil servants (Beamte), for which the peak association DBB remains a competitor, at least as a pressure group Beamte have no right to strike and there is no wage bargaining only consultation.

Union pluralism along religious and white-collar lines remains important in the Benelux countries and in Switzerland. The Christian ACV/CSC is the largest Belgian union confederation (with 54 per cent), followed by the Socialist ACVV/FGTB (39 per cent) and the smaller liberal union centre. Thanks to institutionalised union securities, all three Belgian union movements have high union density and slightly growing membership figures. Despite the merger between Socialist and Catholic union confederations in 1981, the Dutch FNV (64 per cent) still faces some competition from the Christian (largely Calvinist) union movement (CNV, 19 per cent) and an independent peak association (MHP, 11 per cent), which includes two federations of independent and civil servants' associations. In Switzerland, the Christian national union confederation (CNG 12 per cent) and the white collar federation (VSA six per cent)—in the shadow of the much larger Socialist union confederation (SGB 52 per cent) and suffering from severe membership decline-decided to create a joint peak organisation Travail.Suisse (18 per cent) as of 2003. The legacy of political and religious cleavages remains in Belgium thanks to institutionalised support (unions administer the unemployment claims), while in the other countries, it has been more difficult to maintain ideologically distinct organisations when facing membership decline and low union density. Although white-collar special interest organisations coexist in the Netherlands and Switzerland, they are less capable of mobilising white-collar employees compared to the Nordic unions. Institutionalised involvement in corporatist policy-making, particularly in the Benelux countries, and the opportunity for competition in workplace elections has also provided support and incentives for the continuation of union pluralism be it along functional or political and religious lines.

Political unionism in France and Southern Europe led to the split between Communist-led union movements and the more reformist unions (except in Greece where it is internalised in political factions). However, there have been efforts by these unions to coordinate united action and to distance themselves from allied political parties over the last two decades. In France, five union confederations have traditionally held representative status for all sectors despite relatively low density. Industrial unionism, though fragmented in many affiliates, prevails in the political union confederations: the communist CGT, left-reformist CFDT, syndicalist CGT-FO, and Christian CFTC. A new union confederation (UNSA) was formed by the independent teachers' federation (FEN), a police union and smaller other public sector unions in 1993, seeking both to expand and gain 'representative status' in the private sector as well. ${ }^{18}$ The French Communist-led CGT has lost its leading role representing 27 per cent of union members vis-à-vis CFDT (34 per cent) under the leadership of Nicole Notat who stepped down in 2003. The CGT achieves only slightly more votes than the CFDT in 'social elections' (for works councils in 2000 and industrial tribunals in 2002) and considerably more than the smaller competing federations, though the 'cadres' organisation CGF-CGC has a strong position among higher grade employees and UNSA in the public sector, particularly education. Public legitimacy, state funding, corporatist representation and bargaining status are largely based on social election results, not on (hard to verify) membership claims. Although dependent on state support and insti-

\footnotetext{
${ }^{18}$ In addition, after the FEN had expelled left-wing factions these founded a rival teachers' union (FSU) in 1993 and several independent unions formed the Group of Ten in the 1980s. This grouping was very active in the 1995 public sector strike (Goetschy, 1998: 365-6).
} 
tutionalised self-administration, these rival union movements are rather reluctant to agree among themselves and most are hesitant to enter concertation with either the former left or the new right government which came to power in 2002.

Italian union movements started to move towards a single federation as early as the late 1970s but divisions over industrial relations and political issues have since reemerged several times. The early 1990s led to major changes in the political system, transforming the Communist Party into a more moderate Left party, the waning of the Socialist Party, and splintering of the Christian Democratic Party into many smaller factions. The three political union movements-the Communist-led CGIL, Christian CISL and Socialist-reformist UIL-missed the opportunity to unite during the renaissance of tripartite concertation in the 1990s. Inter-union relations are once again strained since the 2001 general elections brought the right coalition government under Berlusconi to power. The tripartite 'Pact for Italy' of 2002 that entailed a 'political exchange' of tax reductions in return for flexible dismissal regulations was strongly opposed by the Communist-led CGIL and accepted by the others, making unity of action and unification less likely in the future (Baccaro et al., 2003). ${ }^{19}$ In contrast to other countries with political unionism, gainfully employed union members are represented relatively equally by a dozen or so sectoral organisations within the main union confederations (excluding the pensioners' unions, which represent half of all members). However, smaller nationalist unions, independent occupational associations and autonomous local movements, particularly in the public sector, have sought to challenge the status of the three 'most representative' confederations in tripartite concertation and bipartite collective bargaining, though without lasting success.

Cooperation between the political union confederations and government-union concertation were mutually reinforcing processes in the Iberian countries (Royo, 2002). The two main Spanish union movements CC.OO and UGT have had traditionally close ties with communist and socialist parties respectively but they have grown more distant since the joint general strike in 'unity of action' against the then Socialist government in 1988 (Hamann, 2001). With increased deregulation by the Conservative government, in power since 1996, the two union confederations were induced to enhance their bargaining roles at all levels. In December 2001, both unions jointly negotiated at national level an inter-sectoral framework agreement with the employers associations. In the Summer of 2002, a general strike was called by both unions against the Conservative government's reform of unemployment insurance that led to some concessions, though there are no signs of overcoming the organisational split into these two main union movements and the smaller regional or other union movements (Fraile, 1999).

The two main Portuguese union confederations-the Communist-led CGTP and the smaller Socialist-reformist UGT-P-maintain closer political ties than their Spanish sister organisations, their internal organisational structure is more territorially fragmented, and 'unity of action' between the two unions has been 'patchy' (Barreto and Naumann, 1998). After the new centre-right government replaced the defeated socialist government in the elections, called early in March 2002, the CGTP called for a general strike in December 2002 against the new proposed Labour Code, while the UGT-P was against a strike and more willing to negotiate with the government in the tripartite CPCS.

Greek political unionism is not externalised but internalised within the main union confederation (GSEE), which is dominated by the Socialist faction (PASKE) since the 1990s, and factions also exist within the independent public sector federation ADEDY (Kristantonis, 1998). GSEE's 2002 congress decided to cooperate more closely, at regional and sectoral level, with the smaller ADEDY, which is expected to pave the way for their eventual merger over the coming years.

\footnotetext{
${ }^{19}$ Agreements signed by the CISL and UIL without the CGIL, in Milan in 2000, and a similar deal in metalworking in 2001, were precedents for the disunity of the three political union confederations. In contrast, all pacts during the 1990s were signed by the three confederations (Regini, 1997).
} 
Developments toward more concentration overcoming political, territorial and occupational fragmentation have been uneven across the Southern countries given their political unionism. Political party alignment and ideological differences are still an obstacle to unity of action, not to speak of eventual merger. The 'most representative' status, legitimacy through social elections, financial support by the state, and state support for collective agreements have helped institutionalise and maintain political unionism despite declining or low union membership and significant socio-economic changes. Cooperation between the main confederations during phases of tripartite concertation, or by joint action against unpopular government policies, has not endured sufficiently to overcome past ideological differences, political alignments, and organisational rivalry.

\section{Conclusion}

Union movements have been and continue to be changing in all European countries towards fewer large unions and more concentrated union movements. The role of unionism in leading collective bargaining is also changing. However, the move towards fewer larger unions has not led to a convergence of union systems across Europe: Cross-national differences still persist and are being renewed. Although British and Irish unions have a considerable record of amalgamation and absorption over the last two decades, the new super-unions straddle sectors and occupational groups in a more disorganised way and have led to more overlap than in other countries. Facing considerable decline in union membership, the forces influencing the development of conglomerate unions have been most pressing in Continental Europe. The Netherlands and Germany have led the way over the last decade, Austria and Switzerland are set to follow suit in the future, while changes are slower in France, Belgium and the Southern European countries. Furthermore in the Nordic countries, with higher levels of unionisation, the trend towards concentration and increased coordination has begun within and across the main union confederations. Yet the moves towards concentration have not led to convergence across Europe. The new super-unions are not following similar multi-sectoral domains, leading to different large unions that compete for leadership within national confederations and in bargaining. In contrast to expectations, the new super-unions have not been able to stop the downward trend in union membership, while the remaining smaller unions are under increased pressure to join larger ones, though some are still surviving in their market niches.

While union concentration has led to some convergence in terms of the smaller number of affiliates, the persistence of political and religious differences and the failure to overcome a plurality of different interests among unions despite the need for more coordination, indicates the salience of national political traditions and organisational self-interest. Although the linkages to political parties are now de-emphasised and the shift from blue-collar towards white-collar employment have made a non-partisan and inclusive strategy more likely, there are only a few signs union pluralism may be overcome. For instance, the Ver.di merger that absorbed the independent white-collar union DAG, the Swiss merger of the Christian-national and white-collar peak organisation in Travail.Suisse, and inter-confederation talks among Finnish unions-remain exceptions and not models indicating a general trend. At the same time, the role of confederations has come under scrutiny as the new super-unions have the financial resources, political power, and administrative capacity to go their own way in national politics, collective bargaining and corporatist institutions. The renaissance of tripartite concertation in some European countries (Molina and Rhodes, 2002) provides a renewed role for confederations, but the importance of following-up at lower bargaining levels and the exit option for employers increases the say of individual sectoral unions vis-à-vis the confederation. Moreover, the traditional leading role of the manufacturing sector within confederations, and in bargaining policy, has been increasingly challenged due to the structural changes towards services, deunionisation in the market sector, and 
new conglomerate service unions. The 'revitalisation' of union movements through organisational restructuring has so far not mobilised union members (Baccaro et al., 2003; Frege and Kelly, 2003). It contains the potential for increased competition between these large players and threatens to weaken union confederations. Although the driving forces behind restructuring will certainly continue to push further organisational changes, the consequences of the new strategy towards ever larger unions will only gradually become apparent in future years.

\section{References}

Arcq, E. and P. Pochet (2000), 'Toward a New Social Pact in Belgium?' in G. Fajertag and P. Pochet (eds), Social Pacts in Europe: New Dynamics (Brussels, ETUI).

Armingeon, K. and S. Geissbühler (eds) (2000), Gewerkschaften in der Schweiz. Herausforderungen und Optionen (Zürich: Seismo).

Baccaro, L., M. Carrieri and C. Damiano (2003), 'The Resurgence of the Italian Confederal Unions: Will it Last?' European Journal of Industrial Relations, 9, 1, 43-59.

Baccaro, L., K. Hamann and L. Turner (2003), 'The Politics of Labour Movement Revitalization: The Need for a Revitalized Perspective', European Journal of Industrial Relations, 9, 1, 119-133.

Barreto, J. and R. Naumann (1998), 'Portugal: Industrial Relations under Democracy', in A. Ferner and R. Hyman (eds), Changing Industrial Relations in Europe (Oxford, Blackwell).

Berger, S. and H. Compston (eds) (2002), Policy Concertation and Social Partnership in Western Europe: Lessons for the 21st Century (New York, Berghahn Books).

Blaschke, S. (2002), 'Gewerkschaftliche Reorganisation in Österreich: der ÖGB auf dem Weg zu einem Bund von Multibranchengewerkschaften', Industrielle Beziehungen, 9, 4, 381-401.

Dølvik, J. E. and T. A. Stokke (1998), 'Norway: The revival of centralized concertation', in A. Ferner and R. Hyman (eds), Changing Industrial Relations in Europe (Oxford, Blackwell).

Ebbinghaus, B. (1996), 'From Ideology to Organization: The Transformation of Political Unionism in Western Europe', in P. Pasture, J. Verberckmoes and H. De Witte (eds), The Lost Perspective? Trade Unions between Ideology and Social Action in the New Europe (2 vols.) (Aldershot, Avebury).

Ebbinghaus, B. (2002a), 'Dinosaurier der Dienstleistungsgesellschaft? Der Mitgliederschwund deutscher Gewerkschaften im historischen und internationalen Vergleich', MPIfG Working Paper, 02, 03.

Ebbinghaus, B. (2002b), 'Trade Unions' Changing Role: Membership Erosion, Organisational Reform, and Social Partnership in Europe, Industrial Relations Journal, 33, 5, 465-483.

Ebbinghaus, B. and A. Hassel (2000), 'Striking Deals: Concertation in the Reform of Continental European Welfare States', Journal of European Public Policy, 7, 1, 44-62.

Ebbinghaus, B. and J. Visser (2000), Trade Unions in Western Europe since 1945 (Handbook and CD-ROM) (London, Macmillan).

EIRO (Doc.No.), EIROnline, http://www.eiro.eurofound.ie.

Fajertag, G. and P. Pochet (eds) (2000), Social Pacts in Europe: New Dynamics (Brussels, ETUI).

Fraile, L. (1999), 'Tightrope: Spanish Unions and Labor Market Segmentation', in A. Martin and G. Ross (eds), The Brave New World of European Labor: European Trade Unions at the Millennium (New York/Oxford, Berghahn Books).

Frege, C. M. and J. Kelly (2003), 'Union Revitalization Strategies in Comparative Perspective', European Journal of Industrial Relations, 9, 1, 7-24.

Gall, G. and S. McKay (2000), 'Facing "Fairness at Work": Union Perception of Employer Opposition and Response to Union Recognition', Industrial Relations Journal, 32, 2, 94-113.

Goetschy, J. (1998), 'France: The Limits of Reform', in A. Ferner and R. Hyman (eds), Changing Industrial Relations in Europe (Oxford, Blackwell).

Hamann, K. (2001), 'The Resurgence of National-Level Bargaining: Union Strategies in Spain', Industrial Relations Journal, 32, 2, 154-172.

Heery, E., J. Kelly and J. Waddington (2003), 'Union Revitalization in Britain', European Journal of Industrial Relations, 9, 1, 79-97.

Kjellberg, A. (2000), 'The Multitude of Challenges Facing Swedish Trade Unions', in J. Waddington and R. Hoffmann (eds), Trade Unions in Europe. Facing Challenges and Searching for Solutions (Brussels, ETUI).

Kristantonis, N. D. (1998), 'Greece: The Maturing of the System', in A. Ferner and R. Hyman (eds), Changing Industrial Relations in Europe (Oxford, Blackwell).

Lijphart, A. (1984), Democracies: Patterns of Majoritarian and Consensus Government in Twenty-one Countries (Princeton, Yale University Press). 
Molina, O. and M. Rhodes (2002), 'Corporatism: The Past, Present, and Future of a Concept', Annual Review of Political Science, 5, 305-331.

Müller, H.-P. (2001), 'Über die Mühen der Profilfindung einer Dienstleistungsgewerkschaft. Zur Entstehungsgeschichte der Multibranchengewerkschaft "Ver.di" im Spannungsfeld von Organisationskonflikten und Programmsuche', Industrielle Beziehungen, 8, 1, 108-137.

Regini, M. (1997), 'Still Engaging in Corporatism? Recent Italian Experience in Comparative Perspective', European Journal of Industrial Relations, 3, 3, 259-278.

Roche, W. K. and J. Larragy (1990), 'Cyclical and Institutional Determinants of Annual Trade Union Growth and Decline in Ireland: Evidence from the DUES Data Series', European Sociological Review, 6, 1, 49-72.

Ross, G. and A. Martin (1999), 'European Unions Face the Millennium', in A. Martin and G. Ross (eds), The Brave New World of European Labor: European Trade Unions at the Millennium (New York/Oxford, Berghahn Books).

Royo, S. (2002), ' "A New Century of Corporatism?" Corporatism in Spain and Portugal', West European Politics, 25, 3, 77-104.

Streeck, W. and A. Hassel (forthcoming), 'Trade Unions and the Political Process', in J. T. Addison and C. Schnabel (eds), International Handbook of Trade Unions (Cheltenham, Edward Elgar).

Streeck, W. and J. Visser (1997), 'The Rise of the Conglomerate Union', European Journal of Industrial Relations, 3, 3, 305-332.

Traxler, F., S. Blaschke and B. Kittel (2001), National Labour Relations in Internationalized Markets. A Comparative Study of Institutions, Change, and Performance (Oxford, Oxford University Press).

Undy, R. (1999), 'The British Merger Movement: The Importance of the "Aggressive" Unions', Industrial Relations Journal, 30, 5, 464-481.

Vandaele, K. (2002), 'De Belgische syndicalisatiegraad: opnieuw aan de beterhand?' Over Werk, $12,157-162$.

Visser, J. (1990), In Search of Inclusive Unionism (Bulletin of Comparative Labour Relations 18) (Deventer, Kluwer).

Visser, J. and J. Waddington (1996), 'Industrialization and Politics: A Century of Union Structural Development in Three European Countries', European Journal of Industrial Relations, 2, 1, 21-53.

Waddington, J. (2000), 'Towards A Reform Agenda? European Trade Unions in Transition', Industrial Relations Journal, 31, 4, 317-330.

Waddington, J. and R. Hoffmann (2000), 'Trade Unions in Europe: Reform, Organisation and Restructuring', in J. Waddington and R. Hoffmann (eds), Trade Unions in Europe. Facing Challenges and Searching for Solutions (Brussels, ETUI). 